\title{
Soil-water dynamics and unsaturated storage during snowmelt following wildfire
}

\author{
B. A. Ebel ${ }^{1}$, E. S. Hinckley ${ }^{2,3}$, and D. A. Martin ${ }^{1}$ \\ ${ }^{1}$ US Geological Survey, Boulder, Colorado, USA \\ ${ }^{2}$ Institute of Arctic and Alpine Research, University of Colorado, Boulder, Colorado, USA \\ ${ }^{3}$ National Ecological Observatory Network, Boulder, Colorado, USA
}

Correspondence to: B. A. Ebel (bebel@usgs.gov)

Received: 14 December 2011 - Published in Hydrol. Earth Syst. Sci. Discuss.: 11 January 2012

Revised: 10 April 2012 - Accepted: 30 April 2012 - Published: 15 May 2012

\begin{abstract}
Many forested watersheds with a substantial fraction of precipitation delivered as snow have the potential for landscape disturbance by wildfire. Little is known about the immediate effects of wildfire on snowmelt and near-surface hydrologic responses, including soil-water storage. Montane systems at the rain-snow transition have soil-water dynamics that are further complicated during the snowmelt period by strong aspect controls on snowmelt and soil thawing. Here we present data from field measurements of snow hydrology and subsurface hydrologic and temperature responses during the first winter and spring after the September 2010 Fourmile Canyon Fire in Colorado, USA. Our observations of soil-water content and soil temperature show sharp contrasts in hydrologic and thermal conditions between northand south-facing slopes. South-facing burned soils were $\sim 1-$ $2{ }^{\circ} \mathrm{C}$ warmer on average than north-facing burned soils and $\sim 1.5^{\circ} \mathrm{C}$ warmer than south-facing unburned soils, which affected soil thawing during the snowmelt period. Soil-water dynamics also differed by aspect: in response to soil thawing, soil-water content increased approximately one month earlier on south-facing burned slopes than on north-facing burned slopes. While aspect and wildfire affect soil-water dynamics during snowmelt, soil-water storage at the end of the snowmelt period reached the value at field capacity for each plot, suggesting that post-snowmelt unsaturated storage was not substantially influenced by aspect in wildfireaffected areas. Our data and analysis indicate that the amount of snowmelt-driven groundwater recharge may be larger in wildfire-impacted areas, especially on south-facing slopes, because of earlier soil thaw and longer durations of soil-water contents above field capacity in those areas.
\end{abstract}

\section{Introduction}

\subsection{Motivation and previous research}

Mountainous regions are important sources of surface and groundwater to downgradient population centers. For example, in the USA over 60 million people depend on water from mountain river basins (Bales et al., 2006). Much of the precipitation in mountain areas falls as snow such that snowmelt contributes the majority of regional water supplies (e.g. Flerchinger et al., 1994; Bales et al., 2006). In the Rocky Mountains of North America, wildfire is one of the most significant events within the disturbance regime (Veblen et al., 1994; Schoennagel et al., 2011), which can affect the quality and quantity of mountain water supplies. In the previous $30 \mathrm{yr}$, wildfire incidence and the duration of fire-prone conditions has increased in the mountainous western USA, which can be partially attributed to earlier snowmelt (Westerling et al., 2006). The trend of increasingly long wildfire seasons and higher wildfire frequency is forecast to continue, with anthropogenically-enhanced global change resulting in shifts to an unprecedented temperature-driven rise in wildfire occurrence (Pechony and Shindell, 2010) and an increase in widespread wildfire synchrony (Kitzberger et al., 2007). The increasing pressure of wildfire and its potential impact on much-needed mountain water supplies (e.g. Ice et al., 2004) creates an imperative that we increase our understanding of wildfire interactions with snowmelt-driven hydrologic response.

Past studies have shown that wildfires can have dramatic consequences for near-surface hydrologic processes, including snow accumulation and melt. Wildfires often devegetate 
the landscape and remove litter and duff by combustion, thereby changing canopy interception, altering near-surface wind velocities, and exposing soil surfaces to the atmosphere. Such wildfire impacts affect snow accumulation and ablation (Billings, 1969; Farnes, 1996; Winkler, 2011) and the radiation balance (Burles and Boon, 2011). Standing dead trees in the burned area play an important role in the energy balance by attenuating wind speed and reducing incoming shortwave radiation (Burles and Boon, 2011). Reported effects of wildfire on snow accumulation are mixed. Silins et al. (2009) found increases in snow-water equivalent (SWE) in burned watersheds by a factor of 2-3 compared to unburned watersheds, which they attributed to canopy removal by the fire. Burles and Boon (2011) documented greater snow accumulation, faster snowmelt, and $30 \%$ more available energy for snowmelt in a burned area compared to a nearby unburned area. Drake et al. (2008), however, found statistically significant reductions in SWE after wildfire, which they attributed to changes in forest cover and canopy structure. While the effects of fire on snow processes can vary by location, we know that post-wildfire changes in snow accumulation and melt can be substantial and ultimately determine the total amount and rate of snowmelt.

Energy balance alterations following wildfire can also affect soil temperatures. Removal of the forest canopy and the insulating layers of litter and duff are the primary causes of soil temperature changes (Bonan and Shugart, 1989), which is compounded by lowering of soil albedo after wildfire (Rouse, 1976; Walker et al., 1986; Chambers et al., 2005). The thermal properties of soils can also be altered by heating during fire (Massman and Frank, 2004). Together, these factors can combine to produce increases in soil temperature following wildfire (Sweeney, 1956; Raison et al., 1986; Auld and Bradstock, 1996; Moody et al., 2007). During the period of snow accumulation and melt, these soil temperature increases cause earlier soil thawing (Bissett and Parkinson, 1980). In areas with seasonal soil freezing, the timing of soil thawing exerts major controls on snowmelt infiltration and soil-water dynamics (Iwata et al., 2010, 2011).

Alteration of hydrologic processes following wildfire has been well documented. This alteration results from, for example, changes in soil-hydraulic properties (e.g. Certini, 2005), including soil-water retention (e.g. Stoof et al., 2010) and hydraulic conductivity (e.g. Nyman et al., 2010). The partitioning of hydrologic fluxes into surface-water, groundwater, and evaporation can be substantially modified following wildfire because of the changed soil-hydraulic properties (Ice et al., 2004; Shakesby and Doerr, 2006) as well as changes in canopy interception (Stoof et al., 2012). One of the main consequences of shifts in hydrologic fluxes may be modifications in soil-water storage. It is well established that soil-water storage is important for many hillslope hydrology processes, such as runoff generation (e.g. TrompVan Meerveld and McDonnell, 2006a, b; Spence, 2007, 2010), groundwater recharge (e.g. Seyfried et al., 2009), and tree/plant survival (e.g. Fahey and Knight, 1986). While known to be a critical component of hydrologic processes, accurate characterization of soil-water storage remains elusive. As noted by McNamara et al. (2011), distributed storage is difficult to quantify at catchment scales because of spatial heterogeneity at the sub-meter scale, resulting in a greater focus on point measurements.

In many mountainous areas, the interactions of wildfire and soil water storage are further complicated by contrasts in hillslope aspect. The distribution of slope aspects in a landscape can have a strong control on soil-water content and vegetation (e.g. Geroy et al., 2011). Differences in energy balance driven by aspect (Monteith and Unsworth, 1990) that control soil temperature (Kang et al., 2000) can affect soil characteristics (Casanova et al., 2000) and soil depths (Khumalo et al., 2008). Snowmelt is influenced by aspect (e.g. Pomeroy et al., 2003) which can affect snowmelt-derived runoff (Shanley and Chalmers, 1999). Aspect effects can be particularly pronounced when slopes are predominantly north- and south-facing, thus maximizing the contrast between incoming solar energy.

It is clear that wildfire and aspect can interact to produce alterations in snowmelt, soil thawing, soil temperature, and soil-water content. Far less is known about how these linked thermal and soil-water impacts control soil-water dynamics and storage during the snowmelt season. Improved understanding of the timing and quantities of snowmelt-driven hydrologic processes is critical in fire-affected areas where snowmelt is a major annual hydrologic event, and hillslope processes cascade to watershed-scale impacts. Sediment transport has been shown to be 2 to 100 times greater in the snowmelt freshet following wildfire (Silins et al., 2009). Much of the snowmelt-derived sediment transport increases are the result of the sustained (i.e. 1 to 4 month) delivery of water to channels, which leads to transport of coarse-grained sediment as bedload (Moody and Martin, 2001; Malmon et al., 2004; Reneau et al., 2007). Elevated streamflow from snowmelt in burned areas can also impact stream channels by increasing nutrient export, removing periphyton, and altering benthic macroinvertebrate assemblages (Minshall et al., 2001). Recent reviews of wildfire impacts on water quality have illuminated the potential detrimental consequences for drinking-water supplies. These impacts are far reaching, including dissolved and particulate constituents (e.g. heavy metals and nutrients), organic matter, and other solutes (Gresswell, 1999; Smith et al., 2011; Emelko et al., 2011). There have been many studies focused on soil-water storage in the unsaturated zone, including snowmelt-dominated environments (e.g. Grant et al., 2004; McNamara et al., 2005; Seyfried et al., 2009; Williams et al., 2009), but almost no research has documented the distribution and persistence of soil-water storage during the snowmelt season following wildfire.

Here we focus on the snowmelt and accompanying subsurface hydrologic response at the hillslope scale in the first 
winter and spring after a fall wildfire. The study was designed to consider the combined impacts of wildfire and aspect on soil temperature and soil-water content during the snowmelt season. Our analysis includes interactions between the soil thermal and hydrologic states that ultimately control soilwater dynamics and soil-water storage. We also compare the burned Fourmile Canyon results to the nearby (i.e. $\sim 6 \mathrm{~km}$ away, $\sim 200 \mathrm{~m}$ higher elevation) unburned Gordon Gulch research catchment of the Boulder Creek Critical Zone Observatory and discuss implications of the hillslope hydrology changes for processes at the watershed scale.

\subsection{Study area}

The study area was the 2010 Fourmile Canyon Fire near Boulder, CO (Fig. 1) in the Colorado Front Range, USA (see Ebel et al., 2012). After initiation on 6 September 2010, extremely dry conditions and high winds drove the rapid spread of the wildfire, which eventually covered 2500 ha and destroyed over 160 residences before full containment on 13 September 2010 (FEST, 2010). High wind velocities and shifting wind directions resulted in a mosaic burn pattern of low, moderate, and high severities (after Keeley, 2009) at ground level. Elevations in the burn perimeter range from $1940 \mathrm{~m}$ to $2620 \mathrm{~m}$.

The area has largely igneous geology. Soils are frigid Lamellic and Typic Haplustalf (USDA, 2010), or Luvisols in the Food and Agriculture Organization of the United Nations (FAO) naming convention, and are classified by particle size as a gravelly sandy loam (Moreland and Moreland, 1975). Before the wildfire, vegetation was typical of the Foothill Pseudotsuga-Pinus ponderosa forest (Peet, 1981) above the transition between foothills and montane ecosystems (Marr, 1961). Aspect had a strong control on prewildfire vegetation in the area impacted by Fourmile Canyon Fire, with north-facing slopes dominated by aspen (Populus tremuloides), Rocky Mountain Douglas fir (Pseudotsuga menziesii subspecies glauca), and Limber pine (Pinus flexilis) and south-facing slopes dominated by ponderosa pine (Pinus ponderosa) (FEST, 2010). The pre-fire vegetation typically burns with moderate to high severity during wildfires, with fire initiation primarily driven by extreme drought (Schoennagel et al., 2011).

The strongly continental climate has cyclonic storms in the winter and localized, convective storms in the summer, resulting in a double-peaked precipitation distribution with a peak in April/May and a second (smaller) peak in July/August driven by the North American monsoon (Barry, 1973). Mean annual precipitation is $\sim 500 \mathrm{~mm}$ at the Fourmile Canyon area (based on the 20-yr period of record at NADP site CO94 at $39.99^{\circ} \mathrm{N}, 105.48^{\circ} \mathrm{W}$; National Atmospheric Deposition Program, NADP, 2011). Approximately 60 to $75 \%$ of water flux to the subsurface is supplied by snowmelt in this region of the Colorado Front Range (Stewart et al., 2004). The study area has disparate snow

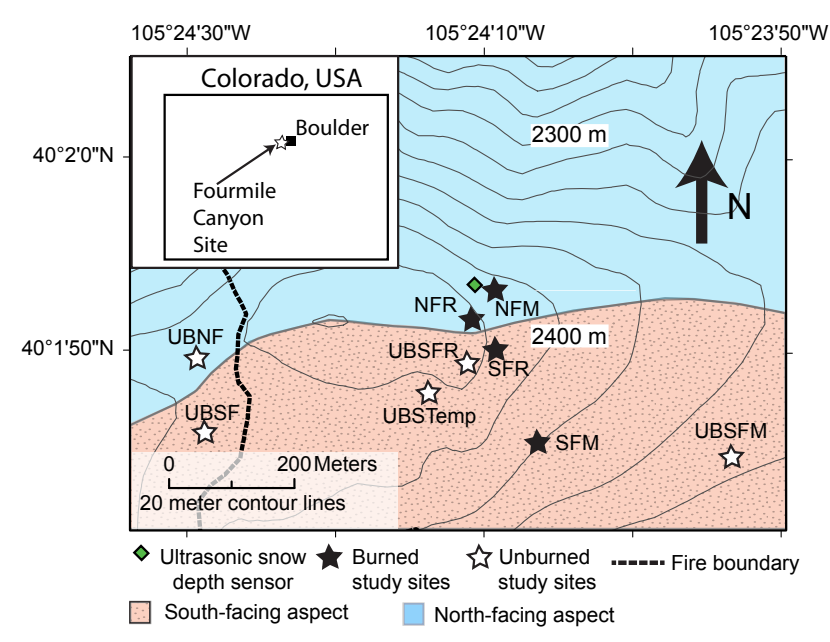

Fig. 1. Map of the experimental plots in the area affected by the 2010 Fourmile Canyon Fire near Boulder, CO, USA. Basemap from Sheila Murphy, US Geological Survey.

accumulation/melt behavior by aspect, with seasonal snowpack development on north-facing slopes (i.e. lasting for weeks to months) and an intermittent snowpack on southfacing slopes (i.e. lasting for days following a storm). This aspect-driven difference in snowpack typically results in a sustained melt-water input to the subsurface during a defined melt season on north-facing slopes in contrast to pulsed inputs of melt-water to the subsurface following storms on the south-facing slopes.

We selected study plots with predominately north- and south-facing aspects at different hillslope positions (ridge and midslope) for instrumentation and measurement (Fig. 1). Study plot characteristics are presented in Table 1. We have described soils that have been impacted by wildfire as "burned", because partial or full combustion of some organic matter has taken place along with heating of mineral soil. Burned plots are south-facing ridge (SFR), southfacing midslope (SFM), north-facing ridge (NFR), and northfacing midslope (NFM). Unburned plots are on south-facing ridge (UBSFR) and south-facing mislope (UBSFM) locations. A temporary site (UBSTemp) was briefly established until research access permission could be gained for additional unburned sites with north-facing (UBNF) and southfacing (UBSF) aspects in April 2011. This study was not a true "fully-factorial" experiment, because there was no fully instrumented unburned north-facing slope for the entire study period (Table 1). Therefore, we focused our comparisons to unburned versus burned south-facing slopes and burned north-facing versus burned south-facing slopes. 
Table 1. Experimental plot characteristics.

\begin{tabular}{|c|c|c|c|c|c|c|c|}
\hline \multirow{2}{*}{ Plot name } & \multirow{2}{*}{ Condition } & \multirow{2}{*}{ Aspect } & \multicolumn{2}{|c|}{ Local slope $\left(^{\circ}\right)$} & \multirow{2}{*}{$\begin{array}{l}\text { Soil depth } \\
\text { (cm) }\end{array}$} & \multirow{2}{*}{$\begin{array}{l}\text { Sensor depths } \\
(\mathrm{cm})\end{array}$} & \multirow{2}{*}{ Measurements ${ }^{\mathrm{c}}$} \\
\hline & & & Range & Mean & & & \\
\hline UBSFM & Unburned & Southeast & $9-19$ & 14 & 49 & $5,10,15$ & TG-SWC, A-SWC,A-T, SWE \\
\hline UBSTemp & Unburned & Southwest & $12-23$ & 16 & - & - & TG-SWC \\
\hline UBSFR & Unburned & South & $15-31$ & 20.5 & 31 & 5,10 & TG-SWC, A-SWC,A-T, SWE \\
\hline UBSF & Unburned & South & $10-22$ & 14 & 51 & - & TG-SWC \\
\hline UBNF & Unburned & North & $10-23$ & 15 & 34 & - & TG-SWC \\
\hline NFM & Burned & North & $15-22$ & 17.5 & 42 & $5,10,15$ & TG-SWC, A-SWC,A-T, SWE \\
\hline NFR & Burned & North & $15-20$ & 17 & 54 & $5,10,30$ & A-SWC,A-T, SWE \\
\hline SFM & Burned & South & $12-19$ & 16 & 30 & $5,10,30$ & A-SWC,A-T, SWE \\
\hline SFR & Burned & South & $12-22$ & 18 & 30 & $5,10,30$ & TG-SWC, A-SWC,A-T, SWE \\
\hline
\end{tabular}

${ }^{\text {a }}$ Soil depths are the maximum value from repetitively driving a steel rod to refusal. ${ }^{\mathrm{b}}$ Sensor depths are for the Decagon 5 TE sensors. ${ }^{\mathrm{c}}$ TG-SWC is thermogravimetric soil-water content, A-SWC is automated soil-water content using the Decagon 5TE sensors, A-T is automated soil temperature using the Decagon 5TE sensors, and SWE is snow-water equivalent.

\section{Methods}

\subsection{Atmospheric and snow measurements}

Snow depths (mm) and air temperatures were measured at the NFM plot with a Judd Communications ultrasonic depth sensor (Judd Communications, Salt Lake City, USA) using 3min temporal resolution and a 1-h running mean of the data to smooth out noise, as recommended by Brazenec (2005). The snow depth sensor was installed at a height of $1.75 \mathrm{~m}$ from the ground surface with the ultrasonic sensor positioned normal to the slope. Measured ultrasonic snow depths were corrected using the slope geometry to a vertical (i.e. Cartesian) snow depth. Manual measurements of snow depth $(\mathrm{mm}), \mathrm{SWE}(\mathrm{mm})$, and snow density $\left(\mathrm{mm} \mathrm{mm}^{-1}\right)$ were made using a ruled tubular sampler with four replicate samples at approximately weekly intervals at all plots. SWE was defined here as the liquid water equivalent contained within the snowpack. Some storm events were not captured by the regular manual sampling, particularly on the south-facing slope which experienced complete melt within days of deposition. Snow density was reported as the ratio of SWE to snow depth. The precipitation record from the nearby Sugarloaf NADP site (CO94 at $39.99^{\circ} \mathrm{N}, 105.48^{\circ} \mathrm{W}$; NADP, 2011) was used as a complete record during the snowmelt season to understand trends when data from the ultrasonic sensor and manual SWE measurements were unavailable. Total precipitation at the Sugarloaf NADP site from 1 December 2010 to 1 June 2011 was $279 \mathrm{~mm}$, which was just slightly above the mean precipitation $(267 \mathrm{~mm})$ for these same dates during the period of record.

\subsection{Soil-water and temperature measurements}

Soil-water content $\left(\mathrm{m}^{3} \mathrm{~m}^{-3}\right)$ and soil temperature $\left({ }^{\circ} \mathrm{C}\right)$ were measured using Decagon 5TE sensors (Decagon Devices, Pullman, WA, USA) at the NFM, NFR, SFR, SFM, UBSFR, and UBSFM plots at 2-min temporal resolution at the depths shown in Table 1 . Sensors are offset in plan-view by $\sim 20 \mathrm{~cm}$ with increasing depth of installation to minimize disturbance of soil overlying the sensors, which makes individual plot size $\sim 1 \mathrm{~m}^{2}$ in terms of the plan-view footprint. The soilwater content measurements from the Decagon sensors were calibrated in the laboratory using disturbed soil samples with the soil from each specific plot using the technique recommended by Cobos and Chambers (2010). The Decagon 5TE sensors estimate unfrozen water content and cannot be used to estimate water content at soil temperatures below freezing without difficult and expensive calibration under freezing conditions (Yoshikawa and Overduin, 2005), so only water content estimates at soil temperatures above $0{ }^{\circ} \mathrm{C}$ were analyzed. Soil temperature was recorded to a precision of $0.1^{\circ} \mathrm{C}$. Volumetric soil-water content was estimated for the top $3 \mathrm{~cm}$ of soil at selected plots (see Table 1) using thermogravimetric methods (Topp and Ferré, 2002). Four replicate, approximately $60-\mathrm{g}$ soil samples were collected at the selected plots on an approximately weekly sampling schedule. Spacing between the replicate core samples at each plot was approximately $5 \mathrm{~cm}$. Samples were sealed in metal cans and processed in the laboratory within $3 \mathrm{~h}$ by drying at $105^{\circ} \mathrm{C}$ for $24 \mathrm{~h}$. Samples were weighed before and after drying on a digital balance to $0.001 \mathrm{~g}$ with an estimated error of $\pm 0.005 \mathrm{~g}$ or $<0.01 \%$. Soil-water storage was estimated from the depth profiles of soil-water content from the automated sensors using numerical integration (a trapezoidal approximation) with the assumption of uniform soil-water content from the $5-\mathrm{cm}$ sensor to the surface. This assumption was required because the Decagon 5TE sensors cannot be installed shallower than 5 -cm depth without compromising the accuracy. During the period of observation of this work (i.e. winter and spring) decreased evaporation lessens soil-water content gradients in the top $5 \mathrm{~cm}$ of soil, thus making this assumption reasonable. 


\subsection{Subsurface characterization and hydrologic properties}

Local slope was measured with an inclinometer (Table 1). Soil depth was measured by pounding in a steel rod to refusal. Multiple measurements (i.e. 3 to 5) were made at each plot and the maximum depth was recorded because large rocks embedded in the soil profile would otherwise bias measurements toward a smaller-than-actual soil depth (Table 1). Soil-water retention curves for intact cores were measured at UBSFM, UBSF, UBNF, NFM, NFR, SFM, and SFR using the hanging column method (Dane and Hopmans, 2002a), a pressure plate (Dane and Hopmans, 2002b), a dewpoint potentiometer (Gee et al., 1992), and a relative-humiditycontrolled chamber (Nimmo and Winfield, 2002). The computer program RETC (van Genuchten et al., 1991) was used to estimate van Genuchten (1980) parameters for the soilwater retention data. Soil-water content at field capacity was estimated using the van Genuchten (1980) relations at a matric potential of $-340 \mathrm{~cm}$, which is 0.33 bar (Richards and Weaver, 1944). While field capacity can differ greatly between soils, using $-340 \mathrm{~cm}$ is consistent with other studies and facilitates intercomparison between our work and results from previous researchers. Porosity was estimated both as the soil-water content at saturation and using bulk density/particle density methods.

\subsection{Quantitative statistics}

Statistical analysis was conducted on the SWE and thermogravimetric soil-water content data using two-tailed, twosample t-tests $(p<0.05)$ assuming unequal variances and on the Decagon 5TE soil-water content and soil temperature data using the non-parametric, two-sided Wilcoxon rank sum test $(p<0.05)$. The statistics toolbox in the Matlab software package was used for both methods. The null hypothesis for the t-test is that the two compared datasets are from the same population, as determined by having the same mean and for the Wilcoxon rank sum test is that the two datasets have the same median.

\section{Results}

\subsection{Air temperature, precipitation and snow-water equivalent}

The meteorological forces driving both the accumulation and melt of the less than 1-m thick seasonal snowpack on the north-facing slope are presented in Figs. 2 and 3. Maximum daily air temperatures declined from above $30^{\circ} \mathrm{C}$ in early November to near/below $20^{\circ} \mathrm{C}$ around 10 November, which also coincided with minimum daily air temperatures dropping to near/below $0{ }^{\circ} \mathrm{C}$ (Fig. 2). This transition in air temperature marked the precipitation phase shift from predominantly rainfall to snow (personal observation). Snowfall amounts in November and December were insufficient to build a seasonal snowpack on the north-facing slope. Most of the seasonal snowpack developed during a prolonged cold period in late January through early February with daily maximum air temperatures below $0{ }^{\circ} \mathrm{C}$ (Fig. 2), combined with two relatively large snowfall events on 6 February and 8 February (Table 2). The subsequent disappearance of the seasonal snowpack around 3 March 2011 was caused by a warm period in late February and early March (Figs. 2 and 3). The decline in SWE coupled with increases in snow density at the north-facing plots (NFM and NFR) led to snowpack disappearance on 10 March, reflecting microtopographic and shading influences on snow accumulation and melt between the ultrasonic sensor and SWE plots (Figs. 3 and 4a, b).

The south-facing burned plots, in contrast, did not develop a seasonal snowpack, but melted off partially within days of storms and fully within a week. Field observations and photographs, for example, showed near-complete disappearance of snow on burned south-facing slopes within a week of the 8 February 2011 storm. SWE measurements, beginning on 15 February, showed zero values in February and March at SFM and SFR. The unburned south-facing plots behaved differently than the burned south-facing plots in February and March, with the UBSFR plot accumulating a snow pack because it was in the leeward side of a ridge just below the crest, allowing wind deposition from the north-facing slopes. This unique topographic position caused the UBSFR plot to accumulate the largest seasonal SWE, yet achieve more rapid SWE disappearance (22 February) than the northfacing slopes (Fig. 4a, b). The other unburned south-facing plot, UBSFM, had a slightly smaller slope (Table 1) compared to the other plots and faces to the southeast, which may have aided in the accumulation of a brief seasonal snowpack that disappeared on the same day as UBSFR, on 22 February. The two-tailed t-tests could not reject (i.e. analyzing two sites at a time) the null hypothesis that the SWE data for the different sites were all from the same population $(p<0.05)$, although the small sample size $(n=11)$ is problematic for this analysis.

A slight increasing trend in air temperature (Fig. 3) and solar insolation after mid March prevented re-establishment of the north-facing snowpack, marking the transition where all the slopes melted off rapidly regardless of aspect. The SWE data for the storms on 12 and 13 April (Fig. 4a) and the snow depth record near NFM (Fig. 3) also reflected this transition. This pattern of rapid melt following storms on both northand south-facing aspects continued until the full transition to precipitation falling as rainfall in early June. Total precipitation from 1 November 2010 to 1 June 2011 was 326-mm water equivalent at the Sugarloaf NADP station.

\subsection{Soil temperature}

Soil temperatures were lower and stayed frozen (i.e. below $0^{\circ} \mathrm{C}$ ) for longer on north-facing slopes, compared to 


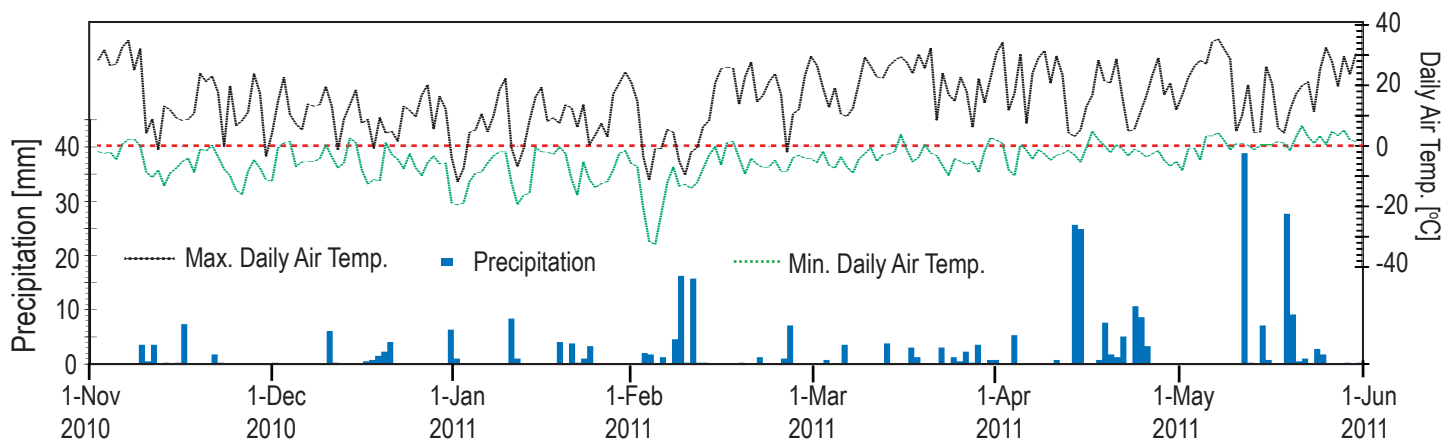

Fig. 2. Time series of precipitation and air temperature from the nearby Sugarloaf climate station (CO94) operated by the NADP program. The dashed red line marks $0^{\circ} \mathrm{C}$ air temperature.

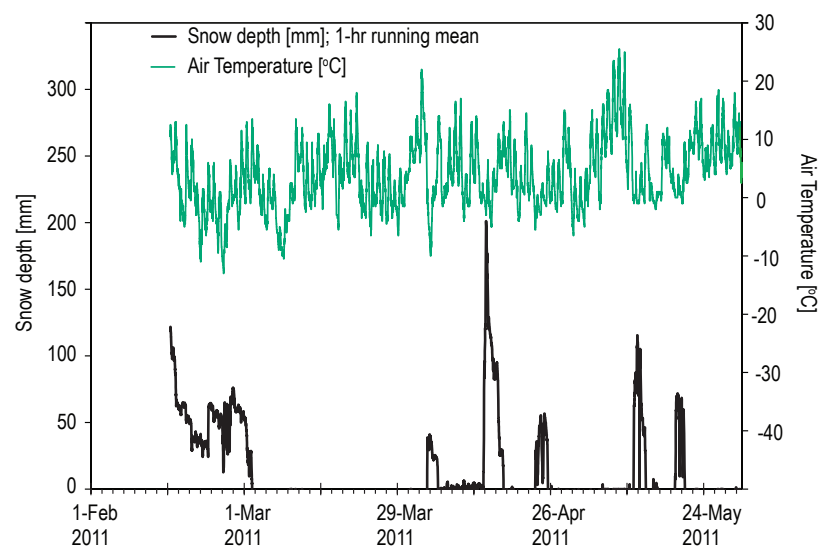

Fig. 3. Time series of snowdepth and air temperature from the ultrasonic sensor at the north-facing midslope (NFM) plot.

south-facing slopes. The onset of soil freezing was remarkably similar, regardless of aspect, with shallow (i.e. $5-10 \mathrm{~cm}$ ) freezing initiated approximately on 25 November (Fig. 5). The primary difference between north- and south-facing slopes was that the north-facing slopes remained frozen nearly continuously from late November to mid March while the south-facing slopes thawed intermittently in response to warm periods (Fig. 5). South-facing slopes did respond to substantial cold periods however, as shown by the frozen conditions re-established during the early February cold period. Aspect-controlled differences for soil temperatures in burned soils are shown by lower mean and median values in Table 3 for north-facing slopes relative to south-facing slopes, by $\sim 2-3^{\circ} \mathrm{C}$, from 1 November 2010 to 1 June 2011 . Effects of wildfire on soil temperature are shown by comparing mean and median soil temperatures for the burned (SFM and SFR) and unburned (UBSFM and UBSFR) south-facing plots in Table 3. Unburned plots had lower mean and median soil temperatures, compared to the south-facing burned plots. In fact, the unburned south-facing plots had mean and median soil temperatures that were more like burned
Table 2. Major precipitation events (i.e. greater than 10-mm water equivalent) at the field area during the study period from 1 November 2010 to 1 June 2010 based on the Sugarloaf NADP data (NADP site CO94 at $39.99^{\circ} \mathrm{N}, 105.48^{\circ} \mathrm{W}$; NADP, 2011). All events are snow except for the 17 May 2011 event, which is a rain/snow mix.

\begin{tabular}{ll}
\hline Date & $\begin{array}{l}\text { Total precipitation } \\
\text { (water equivalent, mm) }\end{array}$ \\
\hline 6 February 2011 & 16.3 \\
8 February 2011 & 15.7 \\
12 April 2011 & 25.7 \\
13 April 2011 & 24.9 \\
22 April 2011 & 10.7 \\
10 May 2011 & 38.9 \\
17 May 2011 & 27.7 \\
\hline
\end{tabular}

north-facing plots (Table 3). South-facing burned slopes are the warmest of the compared plots (Table 3).

The end of frozen soil conditions was also impacted by both aspect and wildfire. North-facing slopes remained frozen nearly continuously until thawing in early to mid March (Fig. 5). South-facing unburned slopes had intermittent freezing from the end of the cold period in mid February to early March at 5- and 10-cm depths and the southfacing unburned slopes were more frequently frozen during this period, relative to the burned slopes. The south-facing burned slopes only intermittently refroze at $5-\mathrm{cm}$ depth, but never refroze at 10 or $30 \mathrm{~cm}$ after mid February. Compared to burned north-facing plots, the south-facing burned plots thawed nearly a month earlier. Cessation of frozen conditions on all slopes was approximately on 10 March (Fig. 5). Aspect and wildfire impacts drove major differences in soil temperatures at 5- and 10-cm depths after the end of freezing conditions (i.e. mid March through 1 June). Warm periods in early to mid April and mid May illustrate how much warmer the south-facing burned plots got in the near-surface (i.e. 5$\mathrm{cm}$ depth) relative to the burned north-facing soils (Fig. 5). At 5-cm depth, south-facing burned plots were, on average, 
$2.5^{\circ} \mathrm{C}$ warmer in April and $1.6^{\circ} \mathrm{C}$ warmer in May compared to burned north-facing soils, and $1.2^{\circ} \mathrm{C}$ warmer in April and $1.3^{\circ} \mathrm{C}$ warmer in May compared to unburned south-facing soils. The Wilcoxon rank sum tests rejected the null hypothesis $(p<0.05)$ comparing each site against all others, essentially showing significant differences between the site median soil temperatures. The large sample size ( $n$ ranged from $1.63 \times 10^{5}$ to $2.0 \times 10^{5}$ data points) makes the distribution very well defined (i.e. constrained) and thus significant differences should be shown even for $p$-values approaching 0 .

Burned soils, regardless of aspect, had larger temporal variability in soil temperature as indicated by the larger standard deviation $(\sigma)$ values at $\mathrm{SFM}, \mathrm{SFR}$, and $\mathrm{NFR}\left(\sim 6^{\circ} \mathrm{C}\right)$ compared to the $\sigma$-values at the unburned UBSFM and UBSFR plots $\left(\sim 5^{\circ} \mathrm{C}\right)$ (see Table 3 ). The NFM plot had a $\sigma$ for soil temperatures closer to the value of $\sim 5^{\circ} \mathrm{C}$ for unburned plots, which was likely the result of reduced solar insolation because of shading resulting from convergent hillslope topography. Damping of temperature fluctuations (i.e. reduced amplitude) with increasing depth is shown by the smaller $\sigma$ values with depth (Table 3 ). Larger mean and median values with increasing depth show, as expected, higher temperatures at depth in the winter (Table 3).

\subsection{Thermogravimetric soil-water content}

Dry soil conditions in November, which persisted from mid September to soil freezing (Moody and Ebel, 2012; Ebel et al., 2012), were largely unchanged during the frozen winter conditions and only slightly increased at the onset of the early March melt events (i.e. 5 to 12 March). The nearsurface (i.e. top $3 \mathrm{~cm}$ ) of soil, sampled by the thermogravimetric soil-water content measurements, showed a large response to the mid April snowstorms for all burned and unburned plots, regardless of aspect (Fig. 6a). Drainage of soilwater and evaporation were more rapid at the south-facing burned plot (SFR), compared to the burned north-facing and unburned plots. The addition of the unburned north-facing plot (UBNF, Fig. 1) in late April provided a comparison for burned and unburned soils for both north- and south-facing aspects. Unsaturated-zone hydrologic response to the 10 May storm showed that peak soil-water content values were similar, 0.3 to $0.35 \mathrm{~m}^{3} \mathrm{~m}^{-3}$, for all soils regardless of aspect or wildfire impact (Fig. 6a). Similar to the response to the mid April storm, the south-facing burned soil lost water by drainage and evaporation more readily than the other plots (Fig. 6a). The null hypothesis that the thermogravimetric data for the different sites (i.e. analyzing two sites at a time) were from the same population $(p<0.05)$ could not be rejected based on the two-tailed t-tests, although the small sample size $(n=11)$ is also an issue for this analysis.

Fine-scale variability in soil-water content, at the 5- to 10$\mathrm{cm}$ separation distances of the thermogravimetric samples on a given day, undergoes a substantial shift from low to high variability during snowmelt. This fine-scale variability (i.e.

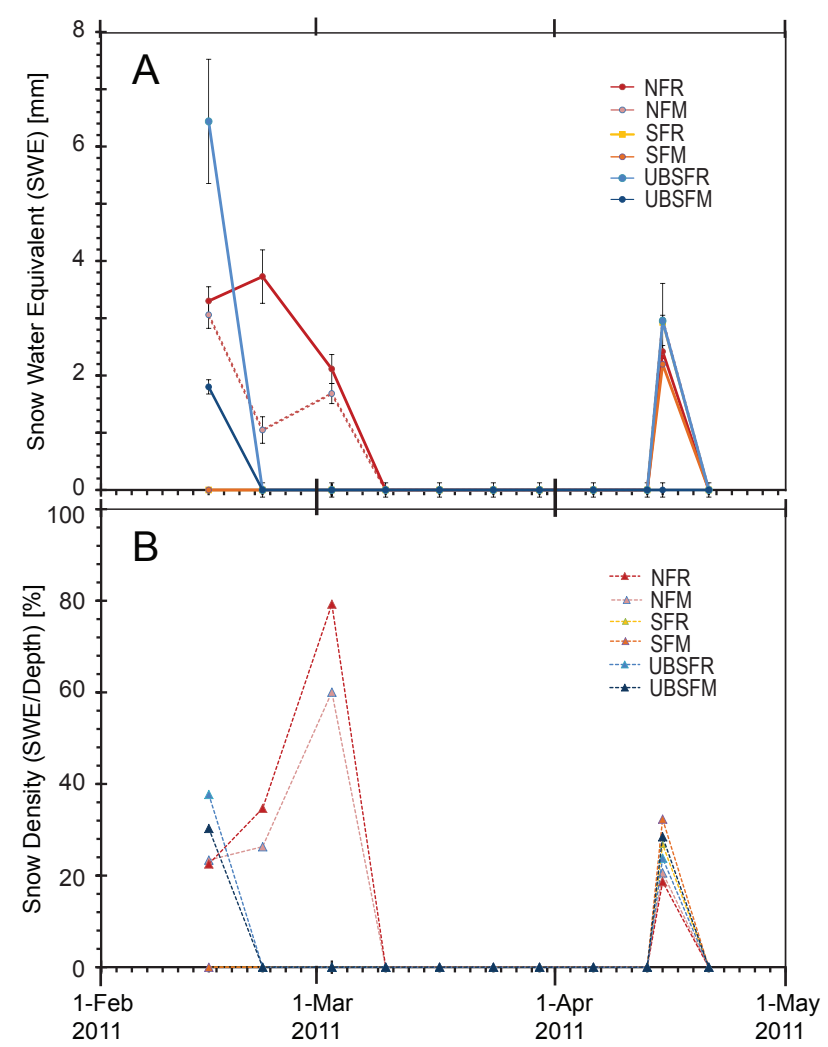

Fig. 4. Time series of snow measurements at the Fourmile Canyon Fire site. (A) Snow-water equivalent (SWE). (B) Snow density (SWE/snow depth).

$5-10 \mathrm{~cm}$ scale) was captured by the between-sample differences of the four replicates taken at each plot on a given day. Immediately following the wildfire the fine-scale soil-water content variability, captured by the coefficient of variation (CV), was high in the burned north-facing area, nearing a value of unity (Fig. 6b). Following the early March melt, and corresponding infiltration of snowmelt water, the variability in soil-water content in the burned north-facing soils declined considerably and approached the variability of the unburned soils (Fig. 6b). Fine-scale soil-water content variability on the north-facing burned slope from April though June was approximately the same as the unburned north- and southfacing soils, regardless of snowmelt inputs, while the southfacing burned soils exhibited greater fine-scale variability, in terms of larger CV (Fig. 6b). Controls of soil-water content on this fine-scale variability were minimal in the unburned soils, where CV appeared to vary independently of soil-water content, as shown by the blue-shaded area in Fig. 6c. In contrast, soil-water content had a moderate to strong control on fine-scale variability in the north- and south-facing burned soils as indicated by the red-shaded area in Fig. $6 \mathrm{c}$. The CV values above 0.5 in Fig. $6 \mathrm{c}$ for the north-facing burned soils were all in the early November data and the snowmelt period reduced the soil-water content control (i.e. wetness) on CV. 
Table 3. Statistics of soil temperature and volumetric soil-water content from the automated sensors (Decagon 5TE).

\begin{tabular}{|c|c|c|c|c|c|c|c|}
\hline \multirow{2}{*}{$\begin{array}{l}\text { Plot } \\
\text { name }\end{array}$} & \multirow{2}{*}{$\begin{array}{l}\text { Sensor } \\
\text { depth }(\mathrm{cm})\end{array}$} & \multicolumn{3}{|c|}{ Soil temperature $\left({ }^{\circ} \mathrm{C}\right)$} & \multicolumn{3}{|c|}{ Soil-water content $\left(\mathrm{m}^{3} \mathrm{~m}^{-3}\right)$} \\
\hline & & Mean & $\sigma^{*}$ & Median & Mean & $\sigma^{*}$ & Median \\
\hline UBSFM & 5 & 3.2 & 4.8 & 1.5 & 0.15 & 0.05 & 0.14 \\
\hline UBSFR & 5 & 3.9 & 4.9 & 2.8 & 0.13 & 0.05 & 0.11 \\
\hline NFM & 5 & 2.3 & 5.1 & 1.4 & 0.12 & 0.04 & 0.12 \\
\hline NFR & 5 & 2.9 & 6.0 & 1.1 & 0.13 & 0.04 & 0.14 \\
\hline SFM & 5 & 5.6 & 6.1 & 4.0 & 0.14 & 0.05 & 0.14 \\
\hline SFR & 5 & 4.6 & 5.9 & 2.6 & 0.19 & 0.05 & 0.18 \\
\hline UBSFM & 10 & 3.5 & 4.1 & 2.4 & 0.14 & 0.04 & 0.13 \\
\hline UBSFR & 10 & 4.1 & 4.2 & 3.5 & 0.14 & 0.07 & 0.13 \\
\hline NFM & 10 & 3.2 & 4.6 & 2.8 & 0.12 & 0.04 & 0.13 \\
\hline NFR & 10 & 2.7 & 5.0 & 1.5 & 0.16 & 0.05 & 0.17 \\
\hline SFM & 10 & 5.1 & 5.2 & 4.1 & 0.17 & 0.04 & 0.17 \\
\hline SFR & 10 & 4.7 & 5.1 & 3.4 & 0.18 & 0.04 & 0.18 \\
\hline UBSFM & 15 & 3.9 & 3.7 & 3.1 & 0.13 & 0.04 & 0.12 \\
\hline NFM & 15 & 2.9 & 4.4 & 2.5 & 0.12 & 0.05 & 0.13 \\
\hline NFR & 30 & 3.5 & 3.8 & 3.3 & 0.12 & 0.07 & 0.06 \\
\hline SFM & 30 & 5.8 & 3.5 & 5.7 & 0.17 & 0.05 & 0.16 \\
\hline SFR & 30 & 5.0 & 4.0 & 4.6 & 0.17 & 0.04 & 0.16 \\
\hline
\end{tabular}

* Standard deviation.

\subsection{Automated soil-water content}

Soil-water content dynamics during snowmelt were controlled primarily by aspect, and less by wildfire impacts. The soil-water content at field capacity (i.e. $-340 \mathrm{~cm}$ ) based on retention curve measurements at each plot and RETCestimated van Genuchten (1980) parameters are shown as dashed lines in Fig. 7. All plots were relatively dry in early November (two months after the fire), especially at the shallow 5- and 10-cm depths, reflecting the prolonged dry period preceding and following the wildfire. Snowfall totaling $18 \mathrm{~mm}$ (SWE) between 9 to 22 November that melted and infiltrated caused rises in soil-water content on the burned and unburned south-facing slopes and also at NFR, but did not considerably affect NFM (Fig. 7). The rise in soil-water content at SFR and SFM from this November storm was ahead of UBSFM and NFR by several days. Because soil-water content is not shown when soil temperature was less than $0^{\circ} \mathrm{C}$, there are large gaps in the soil-water content record for the north-facing slopes in Fig. 7, which are shown by the dark blue bars in the figure. North-facing burned slopes had essentially the same soil-water content at the start of thaw in early March as when the soil froze in December, suggesting that soil-water dynamics were minimal during this three-month period. In contrast, the burned and unburned south-facing slopes remained hydrologically active, in terms of dynamic soil-water contents, throughout the period from December to early March, punctuated by periods of intermittent freezing (Fig. 7). The burned and unburned south-facing soils behaved similarly during December to early March, although UBSFR had very little change in soil-water during this time.
Large and rapid increases in soil-water content, above field capacity, happened in mid February following the frozen period for south-facing burned and unburned slopes. This shift in soil water response was presumably due to soil thawing. North-facing slopes did not show a rise in soil-water content in response to thawing until early March, and the response was more gradual and greatly reduced in magnitude relative to the south-facing slopes (Fig. 7). The north-facing slopes did not have soil-water contents above field capacity in response to the March thawing period; it took more than a month longer, until the response to the 12-13 April storms for the north-facing slopes to rise above field-capacity. Both the 12-13 April, 10 May and 17 May storms drove soil-water contents at all plots above field capacity and all plots, except UBSFM, remained near field capacity at the end of the snowmelt season on 1 June (Fig. 7).

North-facing slopes tended to be drier than the southfacing slopes, based on mean and median soil-water contents (Table 3$)$. The null hypothesis $(p<0.05)$ was rejected, comparing each site against all others, by the Wilcoxon rank sum tests essentially showing significant differences between the site median soil-water contents. Similar to the soil temperature data, the large sample size ( $n$ ranged from $1.6 \times 10^{5}$ to $2.0 \times 10^{5}$ data points) makes the distribution very well defined (i.e. constrained) and thus significant differences should be shown even for $p$-values approaching 0 . Unlike soil-temperature, there were no substantial differences in variability in soil-water contents driven by aspect or wildfire impacts, based on the $\sigma$ values in Table 3 . There are no major differences between the mean and median soil-water contents between the burned and unburned 


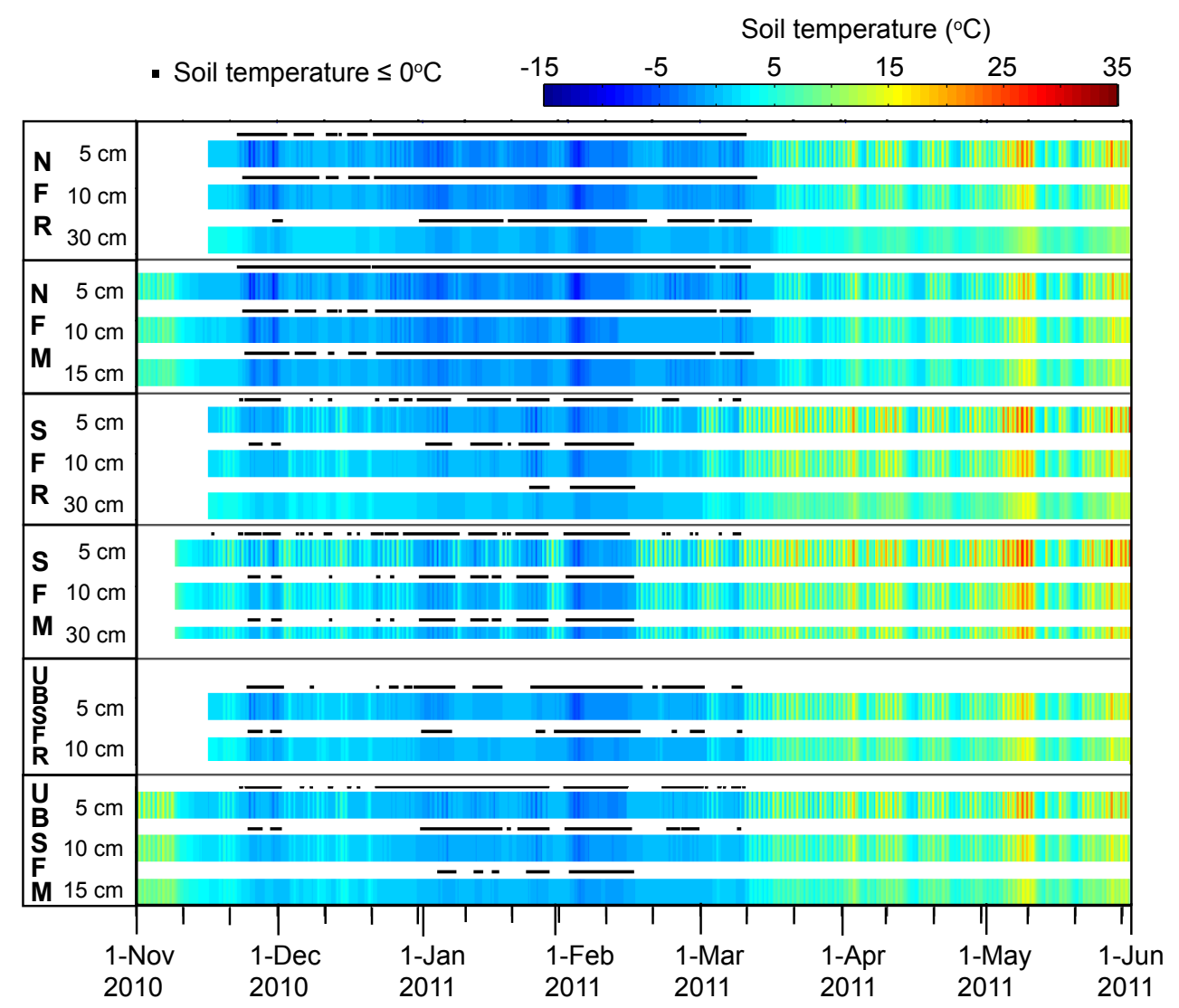

Fig. 5. Soil temperature time series from Decagon 5TE sensors as colored bars with black dots denoting frozen soil. Note that the 2-min temporal resolution gives the black dots denoting frozen conditions the appearance of broken lines.

south-facing plots, although UBSFR was drier overall, possibly because of its ridgetop position and shallow, welldrained soils. Probability histograms of soil-water content at the plots further illustrate differences in soil-water dynamics between plots (Fig. 8). NFM had a strongly bimodal distribution of soil-water contents, with low soil-water contents $\left(\theta<0.1 \mathrm{~m}^{3} \mathrm{~m}^{-3}\right)$ in the pre-melt period and high soil-water contents $\left(\theta>0.1 \mathrm{~m}^{3} \mathrm{~m}^{-3}\right)$ in the post-melt period. NFR did not have the same bimodal distribution as NFM, instead dry conditions persisted at the $30-\mathrm{cm}$ depth and then abruptly shifted to very wet conditions along with the $5-$ and $10-\mathrm{cm}$ depths, which is also shown in the time series in Fig. 7. SFR had a slightly bimodal distribution of soil-water content, similar to NFM, but with far fewer values at low soil-water contents and more values at high soil-water contents, reflecting the earlier melt, and thus more time was spent in a wet state compared to the north-facing slopes. SFM had a pronounced lower soil-water content peak in the distribution for the $5-\mathrm{cm}$ depth, reflecting the slow transition from dry to wet during melt water inputs (relative to SFR) (Figs. 7 and 8). The UBSFR soil-water content distribution was more uniform than the other plots, but shifted overall to drier conditions. At UBSFM, the soil-water content distribution shows a distinct peak between 0.13 to $0.15 \mathrm{~m}^{3} \mathrm{~m}^{-3}$ and slight shift and long tail towards the higher soil-water content range.

\subsection{Unsaturated storage}

Unsaturated storage, estimated by integration of the automated soil-water content measurement profiles, mimicked the soil-water content trends shown previously (see Fig. 9). South-facing burned plots had large increases in soil-water storage beginning in mid February at the initial major thaw with large increases in soil-water storage, especially at the 30-cm depth, from the 12-13 April, 22 April, 10 May, and 17 May storms (Fig. 9). North-facing burned plots had slow rises in soil-water storage with the initial thaw in early March and much larger increases in soil-water storage in response to the 12-13 April, 22 April, 10 May, and 17 May storms. UBSFM had essentially the same trends in soil-water storage as the south-facing burned plots. The UBSFR plot showed a slow rise in soil-water storage in mid-February and responded to the same spring storms as the other plots. Unsaturated soil-water storage at the end of the season (i.e. 1 June) was remarkably similar for all plots, with total water at depths of $0-10 \mathrm{~cm}$ amounting to approximately $2 \mathrm{~cm}$ at SFM, SFR, UBSFM, and UBSFR and slightly lower total amounts 

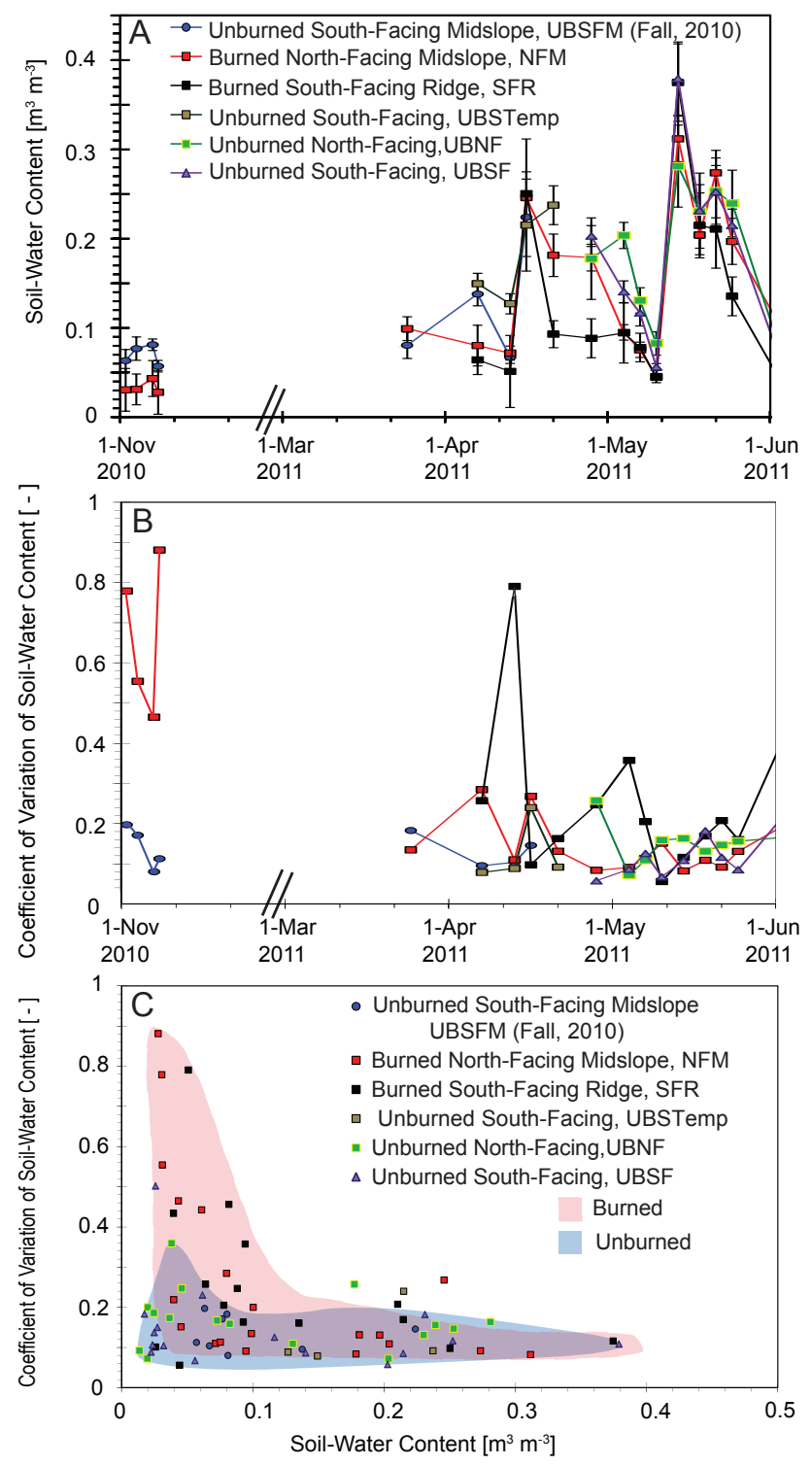

Fig. 6. Thermogravimetric soil-water content from the top $3 \mathrm{~cm}$ of soil. (A) Time series of soil-water content at selected plots. Error bars represent the standard deviation of four replicate measurements at each plot. (B) Time series of the coefficient of variability of soilwater content for the four replicate samples at each sampling date. (C) Graph of the coefficient of variability of soil-water content as a function of the mean soil-water content for that sampling date. Note that the time scales in (A) and (B) have breaks from the end of November 2010 to the beginning of March 2011.

at depths of $0-10 \mathrm{~cm}$ of approximately 1.3 to $1.7 \mathrm{~cm}$ at the north-facing NFM and NFR plots (Fig. 9). The unburned UBSFM plot held more water at the end of the snowmelt season than the burned north-facing NFM plot based on the storage amounts at depths of 0 to $15 \mathrm{~cm}$. The two south-facing burned plots SFM and SFR stored more soil-water at the end of the snowmelt season (approximately $6 \mathrm{~cm}$ ) compared to the north-facing NFR plot (approximately $5.2 \mathrm{~cm}$ ) based on the 0 to $30 \mathrm{~cm}$ storage amounts at depths of 0 to $30 \mathrm{~cm}$.

\section{Discussion}

The goal of this research was to examine the soil-water dynamics, soil-water storage, and soil temperature changes during the snowmelt season following wildfire in a montane environment. Because of the important role of aspect in snowmelt-driven hydrologic processes and soil temperatures, we instrumented north- and south-facing plots in this study. In this section, we present important conclusions from our results, discuss the context of our findings relative to previous work, and introduce broader-scale implications of our research.

\subsection{Soil-water dynamics and unsaturated storage}

In the top $3 \mathrm{~cm}$ of soil peak soil-water contents in response to April and May snow storms (as determined by the thermogravimetric soil-water content measurements) were similar regardless of aspect or wildfire impact, although the largest peak soil-water contents were for the south-facing unburned slope, UBSF (Fig. 6). South-facing burned slopes, however, had more substantial water loss by drainage and evaporation in the top $3 \mathrm{~cm}$ following peak soil-water contents, compared to unburned south-facing and burned and unburned north-facing slopes (Fig. 5). At greater depths, observed by the automated soil-water content sensors, aspect played a stronger role than wildfire in dictating the onset of soil-water content increases during spring thaw (Fig. 7). North-facing slopes were drier than south-facing slopes during the snowmelt period (Figs. 7 and 8). For south-facing plots, mean and median soil-water contents from the automated sensors showed little impact from wildfire effects. This result is consistent with other wildfire research in the Rocky Mountains of Colorado during the snowmelt period. For example, Moody et al. (2007) found no significant differences in soil-water content measured at burned and unburned plots using time-domain reflectometry (TDR) in the winter of 2003-2004. Obrist et al. (2004) measured soilwater contents using TDR in burned and unburned plots in a sagebrush ecosystem and found lower soil-water contents (and consequently lower soil-water storage) during the winter months, which they attributed to decreased snow accumulation in their burned plots.

Soil-water storage at the end of the snowmelt season was relatively unaffected by aspect or wildfire, essentially converging to the value at field capacity. Values of field capacity were slightly different at each plot (Fig. 9). This finding is important because it suggests that the very dry soil conditions that could limit plant regeneration, established before the wildfire and exacerbated in the top $5 \mathrm{~cm}$ during the wildfire (Moody and Ebel, 2012), can be erased during snowmelt. 


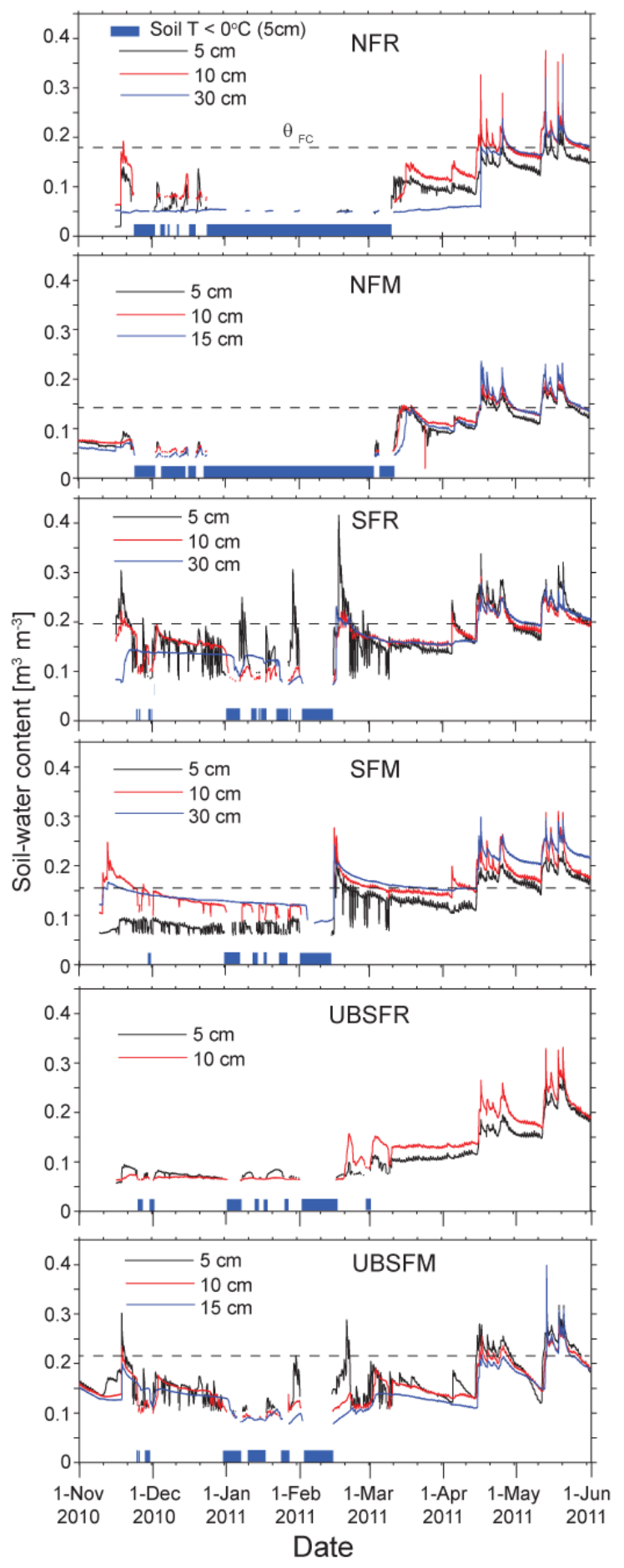

Fig. 7. Automated soil-water content time series from the Decagon 5TE sensors at 1-min temporal resolution. Water content data are omitted when soil temperature is below $0{ }^{\circ} \mathrm{C}$, which is shown by dark blue bars. The dashed line shows the soil-water content at field capacity $\left(\theta_{\mathrm{FC}}\right)$ based on measured retention curves (one per site) and van Genuchten (1980) relationships at each plot. No retention curve was measured for UBSFR so no $\theta_{\mathrm{FC}}$ value is available.
It should be noted that the snowmelt season is typically the apex of soil-moisture in montane environments of the Rocky Mountains. At our field site, it appears that water supply to the subsurface during the snowmelt season was sufficient to drive soil-water content above field capacity, resulting in substantial soil-water storage at the end of the snowmelt season, regardless of aspect or wildfire effects. Our results showed, however, that wildfire effects and aspect can have strong controls on the timing of increased soil-water storage in response to spring thawing and melting of the snowpack. We found that south-facing burned plots had larger magnitude increases in soil-water storage relative to unburned south-facing slopes in response to spring thawing. Our results also showed that increases in soil-water storage were both earlier and larger in magnitude on burned south-facing slopes relative to burned north-facing slopes. These results, in terms of aspect controls on the onset of soil-water storage dynamics, are consistent with previous work at unburned plots, with south-facing slopes having earlier onset of snowmelt than north-facing slopes (Grant et al., 2004; Litaor et al., 2008; Williams et al., 2009). The paucity of other studies documenting wildfire impacts on soil-water storage prevents comparative assessment of our work in terms of wildfire effects.

\subsection{Soil-temperature changes}

Our observations of soil temperature showed that aspect has a large impact on soil-temperature, with south-facing burned slopes being $\sim 1$ to $2{ }^{\circ} \mathrm{C}$ warmer than north-facing burned slopes, reflecting a difference in solar insolation. Other investigators found similar results on unburned slopes. For example, Franzmeier et al. (1969) measured $\sim 2{ }^{\circ} \mathrm{C}$ warmer soils on south-facing slopes in the Appalachian Plateau, USA. The work by Kang et al. (2000) documented that the daily maximum-minimum soil temperature range and the daily average soil temperature were larger on south-facing slopes (in a non-wildfire impacted area in a deciduous forest in Korea). Kang et al. (2000) also noted that the aspect differences in soil-temperature disappeared as the vegetation canopy closed later in the growing season, which suggests that canopy removal by fire is a main driver of soil-temperature differences by aspect, exacerbating solar insolation differences between aspects in unburned areas.

We also observed, on average, $\sim 1-2{ }^{\circ} \mathrm{C}$ higher temperatures on south-facing burned slopes, relative to south-facing unburned slopes, and larger temperature variability in burned slopes. Previous studies showed increased soil temperatures because of decreases in soil albedo (Chambers et al., 2005; Rouse, 1976). Soil albedo reductions can be relatively large after wildfire, for example, Rouse (1976) documented a decrease from 0.19 to 0.05 after wildfire and Chambers et al. (2005) measured burned soil albedos as low as 0.04 . It has also been suggested that surface soil temperature increases following wildfire also result, in part, from incident radiation 


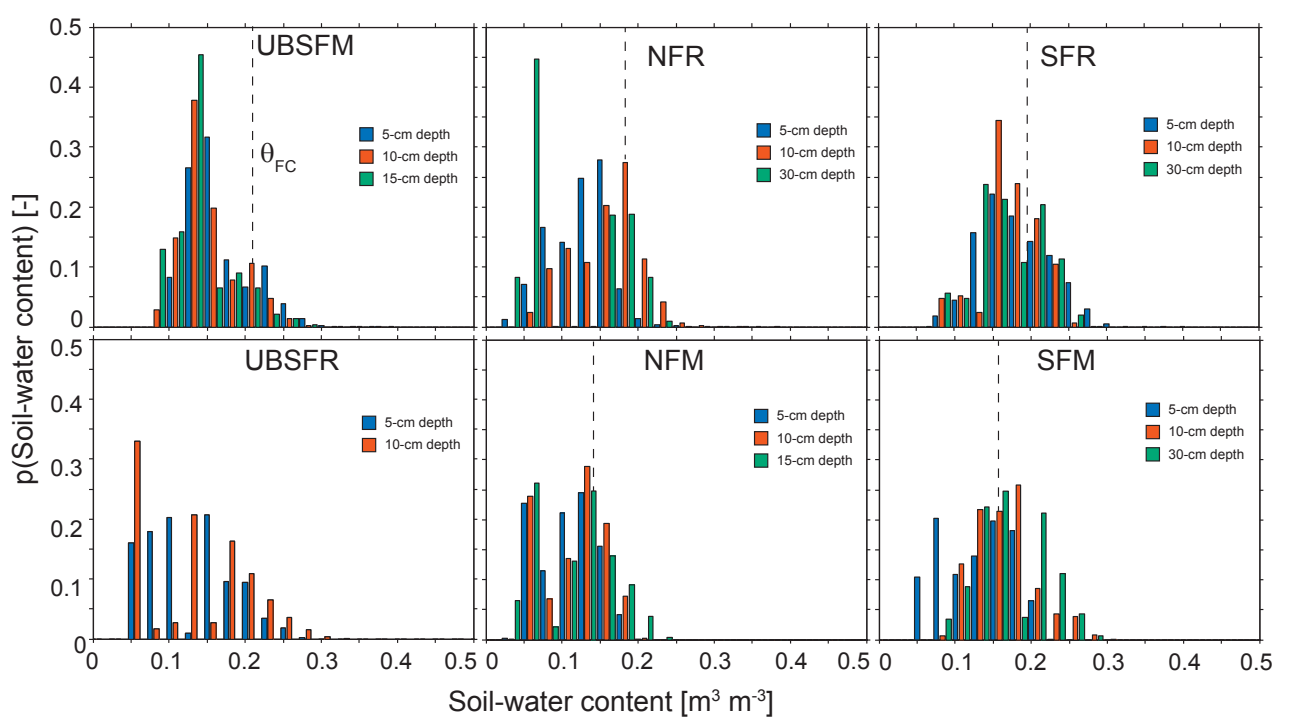

Fig. 8. Probability histograms of automated soil-water content data from the Decagon 5TE sensors.

being distributed over a smaller surface area after devegetation (Chambers et al., 2005).

The soil-temperature changes observed here after wildfire could substantially affect landscape and ecosystem function. Soil temperature changes can increase carbon fluxes from soils to the atmosphere (e.g. Trumbore et al., 1996) and affect nutrient availability (van Cleve et al., 1983). Soil temperatures can affect soil-water retention, which can enhance drainage of soil-water (Nimmo and Miller, 1986). For example, Klock (1972) found that increasing the temperature of a soil column near freezing caused a significant decrease in water retention. Soil temperature is also important for root growth (e.g. Kasper and Bland, 1992; McMichael and Burke, 1998) and can affect plant phenology (e.g. Walker et al., 1995; Price and Waser, 1998). Increased soil temperatures after wildfire can also influence important vegetation recovery processes such as seed dormancy breaking and germination (Auld and Bradstock, 1996). The potential for ecologic and landscape function impacts or impairment, resulting from soil temperature increases following wildfire, exists at the watershed scale for a broad range of processes. Our results suggest that in the snowmelt season, wildfire effects on soil temperature and concomitant process changes would be most pronounced on south-facing slopes.

\subsection{Comparison of soil-water dynamics to the unburned Gordon Gulch field site}

Gordon Gulch research catchment, which is part of the Boulder Creek Critical Zone Observatory, was instrumented in the spring of 2010 to examine snowmelt dynamics and nitrogen cycling. The unburned Gordon Gulch site was close (i.e. $\sim 6 \mathrm{~km}$ away, $\sim 200 \mathrm{~m}$ higher elevation) and was similarly instrumented to the burned Fourmile Canyon site, which facilitated comparison of the unsaturated hydrologic response at these two sites. The snowmelt-driven soil-water dynamics at these two sites differed greatly. Subsurface flow processes for the unburned Gordon Gulch site showed strong aspect-affected differences, with north-facing slopes dominated by diffuse unsaturated flow (i.e. through the soil matrix) and south-facing slopes dominated by event-driven preferential flow in the unsaturated zone (Hinckley et al., 2012). These process distinctions at the unburned Gordon Gulch site were supported by tracer data. South-facing soils remained dry while north-facing soils were wetter at Gordon Gulch and these differences persisted through the entire snowmelt period to June 2010. The burned Fourmile Canyon Fire site examined in this study showed the opposite response, with drier north-facing slopes during the spring thaw and convergence of slopes to similar soil-water contents near field capacity regardless of aspect or wildfire effects. While tracer data were not collected to examine preferential flow at the Fourmile Canyon site, the soil-water content and soil-water storage data suggest predominantly diffuse unsaturated flow on both north- and south-facing plots for burned soils. Soils and vegetation communities are similar between the two sites. The Gordon Gulch site was instrumented during snowmelt season of 2010, the year prior to Fourmile Canyon site, when precipitation from 1 December to 1 June was $304 \mathrm{~mm}$, which was $25 \mathrm{~mm}$ more than at the Sugarloaf NADP during the period considered for the Fourmile Canyon site presented here. The reasons for the contrasting hydrologic behavior during snowmelt between the burned Fourmile Canyon area and the unburned Gordon Gulch area could be, for example, wildfire impacts on subsurface preferential flow. Ash from wildfire has been demonstrated to minimize preferential flow by clogging macropores (Neary et al., 1999; Woods and Balfour, 2010), potentially preventing substantial water flux passing 

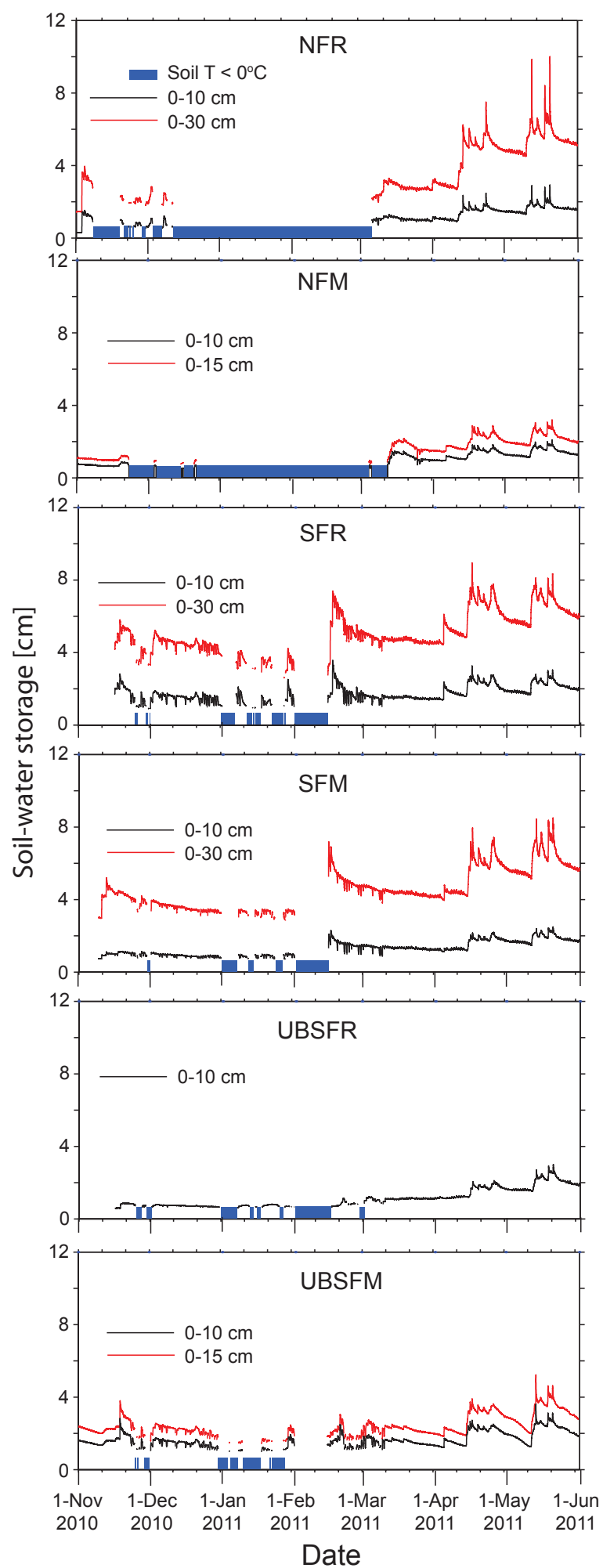

Fig. 9. Soil-water storage during the snowmelt season based on trapezoidal integration of the depth profiles from the Decagon 5TE sensors. Storage estimates are not calculated when soil temperature is below $0{ }^{\circ} \mathrm{C}$, which is shown by dark blue bars. through those macropores (Woods and Balfour, 2010). Another possible explanation is reduced soil structure and soilwater retention following wildfire. Heating of soil by fire has been shown to cause changes in porosity (e.g. Stoof et al., 2010), aggregate stability (e.g. García-Corona et al., 2004; Bento-Gonçalves et al., 2012), and soil structure (e.g. DeBano et al., 1998; Mataix-Solera et al., 2011). Analysis of the soil-water retention data from the burned south-facing slopes in the Fourmile Canyon area showed porosity losses of $\sim 0.1\left(\mathrm{~m}^{3} \mathrm{~m}^{-3}\right)$ and decreased soil-water retention at matric potentials greater than field capacity (Figs. 7 and 8), compared to unburned slopes. Given that soil structure is known to promote macropore flow (e.g. Flury et al., 1994; Ghodrati and Jury, 1992), the loss of structure following wildfire at the south-facing Fourmile Canyon sites may have impeded preferential flow initiation. Thus, the presence of ash at the burned Fourmile Canyon plots or reductions in soil structure that serve as preferential flow paths may explain why preferential flow did not occur as a dominant process on southfacing slopes, in contrast to unburned Gordon Gulch. This study only documented the first year after wildfire, when impacts are typically most pronounced; the wildfire-driven differences in preferential flow significance between the burned Fourmile Canyon and unburned Gordon Gulch sites may dissipate as the Fourmile Canyon area recovers.

\subsection{Implications for watershed-scale processes}

Our results suggest that south-facing burned slopes experience an earlier thaw, accompanied by a rise in soil-water content, compared to both unburned south-facing slopes and burned north-facing slopes. In particular, the soil-water contents (Fig. 7) at SFM and SFR rise above field capacity for sustained periods of time, suggesting groundwater recharge may be occurring at these plots for longer durations relative to NFR, NFM, UBSFM, and UBSFR. Research by Bossong et al. (2003) showed that groundwater recharge in semi-arid environments in the Front Range of Colorado is highly seasonal, with most of recharge occurring during and after snowmelt. Changes in groundwater recharge are then likely to be one of the most substantial watershed-scale impacts of the aspect and wildfire-effect driven soil-water dynamics during the snowmelt season that we have observed at the hillslope scale. Our findings suggest that in montane environments affected by wildfire, snowmelt-driven groundwater recharge may be greater in burned areas, and greatest on burned south-facing slopes. We do not, however, have deep wells (i.e. 10's to 100's of meters) to document water table rises. Thus, our connection of near-surface soil-water dynamics to larger scale groundwater system responses is speculative.

Previous work on post-wildfire groundwater recharge suggested that recharge rates may be greater after fire (Bellot et al., 2001), which was attributed to decreased transpiration fluxes. After plant populations recover, however, the 
post-wildfire plant succession can cause decreased recharge relative to pre-wildfire vegetation assemblages, as was observed by Obrist et al. (2004) in a snowmelt-driven recharge environment. Plant population recovery then places a strong control on the duration of potential increases in post-wildfire groundwater recharge. At the Fourmile Canyon field area characterized in this study, vegetation recovery is complex. In the first summer after the wildfire (i.e. following the snowmelt period), striking differences existed in the vegetation regrowth on burned south- and north-facing slopes. By mid-summer 2011, the south-facing slopes were covered with dense vegetation comprised of weedy annuals such as mullein (Verbascum thapsus), lamb's quarters (Chenopodium spp.) and tumble mustard (Sisymbrium altissimum) and perennial species such as larkspur (Delphinium nuttalianum) and bee balm (Monarda fistulosa), which probably resprouted from undamaged underground roots. By contrast there was little growth of any vegetation on the burned north-facing slopes except for occasional tufts of an unidentified grass. This disparity in vegetation growth may reflect differences in the seed bank on the two aspects, because prior to the fire the north-facing aspect had a closedcanopy Douglas-fir overstory with almost no understory vegetation. We speculate the growth of vegetation on the southfacing burned slopes could be a response to soil-moisture and temperature conditions during the winter and snowmelt period that primed (Hartmann et al., 2011) the seeds of annuals for germination in the early spring. Thus, the period of enhanced snowmelt-driven groundwater recharge on burned south-facing slopes may be relatively brief (i.e. a few years or less), depending on vegetation recovery. If an aspectcontrolled asymmetry develops in groundwater recharge after wildfire, it may drive an emergent asymmetry in baseflow contributions to streamflow in burned watersheds that affects channel geomorphology and riparian areas if the asymmetry is of sufficient duration. This potentially important aspect asymmetry in groundwater supply to streams has yetto-be quantified biogeochemical and geomorphologic consequences.

\section{Conclusions}

We measured snow-water equivalent, snow depth, soil temperature, and soil-water content as well as estimated soilwater storage for the first winter and snowmelt season following the 2010 Fourmile Canyon Fire in CO, USA. Comparison of burned north- and south-facing slopes showed that north-facing slopes developed a short-lived ( $\sim 1$ month) snowpack while south-facing slopes did not. Soil temperatures were $\sim 1-2{ }^{\circ} \mathrm{C}$ lower on average and stayed below $0{ }^{\circ} \mathrm{C}$ longer on north-facing burned slopes, relative to southfacing burned slopes. This aspect-driven soil temperature effect exacerbated by wildfire resulted in north-facing slopes being frozen nearly continuously from late November to mid
March, while both burned and unburned south-facing slopes thawed intermittently throughout the winter and achieved seasonal thaw $\sim 1$ month earlier than north-facing burned slopes. Soil-water dynamics were impacted by both aspect and wildfire, with more rapid soil-water content increases on south-facing burned slopes compared to same-aspect unburned slopes, and more rapid rises on south-facing burned slopes compared to north-facing burned slopes. Histograms of soil-water contents show that south-facing slopes were more frequently wet (i.e. higher soil-water contents) than north-facing slopes, which was likely the result of the earlier thaw on south-facing slopes. Soil-water storage increased earlier in response to the earlier thaw on south-facing slopes, relative to north-facing slopes, however soil-water storage was similar regardless of aspect or wildfire impacts at the end of the snowmelt season in early June.

Acknowledgements. This manuscript benefited from discussions with Benjamin Mirus, John Moody, Sheila Murphy, and Jeffrey Writer. Kim Perkins and two anonymous reviewers provided suggestions that improved the manuscript. Brian Ebel received support from the Mendenhall Postdoctoral Fellowship Program in the National Research Program of the US Geological Survey. Eve-Lyn Hinckley received support from the National Science Foundation Earth Sciences Postdoctoral Fellowship Program (EAR 0847987). Any use of trade, firm, or product names is for descriptive purposes only and does not imply endorsement by the US Government.

Edited by: I. van Meerveld

\section{References}

Auld, T. D. and Bradstock, R. A.: Soil temperatures after the passage of a fire: Do they influence the germination of buried seeds?, Aust. J. Ecol., 21, 106-109, 1996.

Barry, R. G.: A climatological transect on the east slope of the Front Range, Colorado, Arctic Alpine Res., 5, 89-110, 1973.

Bales, R. C., Molotch, N. P., Painter, T. H., Dettinger, M. D., Rice, R., and Dozier, J.: Mountain hydrology of the western United States, Water Resour. Res., 42, W08432, doi:10.1029/2005WR004387, 2006.

Bellot, J., Bonet, A., Sanchez, J. R., and Chirino, E.: Likely effects of land use changes on the runoff and aquifer recharge in a semiarid landscape using a hydrological model, Landscape Urban Plan., 55, 41-53, 2001.

Bento-Gonçalves, A., Vieira, A., Úbeda, X., and Martin, D.: Fire and soils: Key concepts and recent advances, Geoderma, online first: doi:10.1016/j.geoderma.2012.01.004, 2012.

Billings, W. D.: Vegetational pattern near alpine timberline as affected by fire-snowdrift interactions, Vegetatio, 19, 192-207, 1969.

Bissett, J. and Parkinson, D.: Long-term effects of fire on the composition and activity of the soil microflora of a subalpine, coniferous forest, Can. J. Botany, 58, 1704-1721, 1980. 
Bonan, G. B. and Shugart, H. H.: Environmental factors and ecological processes in boreal forests, Annu. Rev. Ecol. Syst., 20, 1-28, 1989.

Bossong, C. R., Caine, J. S., Stannard, D. I., Flynn, J. L., Stevens, M. R., and Heiny-Dash, J. S.: Hydrologic conditions and assessment of water resources in the Turkey Creek Watershed, Jefferson County, Colorado, 1998-2001, Water-Resources Investigations Report 03-4034, US Geological Survey, Denver, CO, 2003.

Brazenec, W. A.: Evaluation of ultrasonic snow depth sensors for automated surface observing systems (ASOS), Masters Thesis, Department of Forest, Rangeland and Watershed Stewardship, Colorado State University, Fort Collins, Colorado, 134 pp., 2005.

Burles, K. and Boon, S.: Snowmelt energy balance in a burned forest plot, Crowsnest Pass, Alberta, Canada, Hydrol. Process., 25, 3012-3029, 2011.

Casanova, M., Messing, I., and Joel, A.: Influence of aspect and slope gradient on hydraulic conductivity measured by tension infiltrometer, Hydrol. Process., 14, 155-164, 2000.

Certini, G.: Effects of fire on properties of forest soils: a review, Oecologia, 143, 1-10, 2005.

Chambers, S. D., Beringer, J., Randerson, J. T., and Chapin III, F. S.: Fire effects on net radiation and energy partitioning: Contrasting responses of tundra and boreal forest ecosystems, J. Geophys. Res., 110, D09106, doi:10.1029/2004JD005299, 2005.

Cobos, D. R. and Chambers, C.: Calibrating $\mathrm{ECH}_{2} \mathrm{O}$ Soil Moisture Sensors, Application Note, Decagon Devices, Pullman, WA, 7 pp., 2010.

Dane, J. H. and Hopmans, J. W.: Hanging water column, in: Methods of soil analysis, Part 4 - Physical methods, Soil Science Society of America Book Series No. 5, edited by: Dane, J. H. and Topp, G. C., 680-683, Soil Science Society of America, Madison, Wisconsin, 2002a.

Dane, J. H. and Hopmans, J. W.: Pressure plate extractor, in: Methods of soil analysis, Part 4 - Physical methods, Soil Science Society of America Book Series No. 5, edited by: Dane, J. H. and Topp, G. C., 688-690, Soil Science Society of America, Madison, Wisconsin, 2002b.

DeBano, L. F., Neary, D. G., and Ffolliott, P. F.: Fire effects on ecosystems, John Wiley \& Sons, New York, 1998.

Drake, E., DeSisto, C., McDonald, S., Evans, S., Barry, D., and Baccus, B.: Untangling Climate and Wildfire Influences from Snow Water Equivalent Measurements on the Deer Park, WA Snow Course, in: Proceedings of the Western Snow Conference, 1517 April, Hood River, Oregon, 2008.

Ebel, B. A., Moody, J. A., and Martin, D. A.: Hydrologic conditions controlling runoff generation immediately after wildfire, Water Resour. Res., 48, W03529, doi:10.1029/2011WR011470, 2012.

Emelko, M. B., Silins, U., Bladon, K. D., and Stone, M.: Implications of land disturbance on drinking water treatability in a changing climate: Demonstrating the need for "source water supply and protection" strategies, Water Res., 45, 461-472, 2011.

Fahey, T. J. and Knight, D. H.: Lodgepole pine ecosystems, BioScience, 36, 610-616, 1986.

Farnes, P. E.: Impact of 1988 Yellowstone fires on snowmelt water yields, in: The Ecological Implications of Fire in Greater Yellowstone, edited by: Greenlee, J. M., International Association of Wildland Fire: Fairfield, Washington, 39-42, 1996.

Flerchinger, G. N., Cooley, K. R., and Deng, Y.: Impacts of spatially and temporally varying snowmelt on subsurface flow in a mountainous watershed: 1. Snowmelt simulation, Hydrolog. Sci. J., 39, 507-520, 1994.

Flury, M., Flühler, H., Jury, W. A., and Leuenberger, J.: Susceptibility of soils to preferential flow of water: a field study, Water Resour. Res., 30, 1945-1954, 1994.

Fourmile Emergency Stabilization Team (FEST): Fourmile Emergency Stabilization Burned Area Report, Boulder County, CO, 14 pp., 2010.

Franzmeier, D. P., Pedersen, E. J., Longwell, T. J., Byrne, J. G., and Losche, C. K.: Properties of some soils in the Cumberland Plateau as related to slope aspect and position, Soil Sci. Soc. Am. J., 33, 755-761, 1969.

García-Corona, R., Benito, E., de Blas, E., and Varela, M. E.: Effects of heating on some soil physical properties related to its hydrological behaviour in two north-western Spanish soils, 761, Int. J. Wildland Fire, 13, 195-199, 2004.

Gee, G. W., Campbell, M. D., Campbell, G. S., and Campbell, J. H.: Rapid measurement of low soil water potentials using a water activity meter, Soil Sci. Soc. Am. J., 56, 1068-1070, 1992.

Geroy, I. J., Gribb, M. M., Marshall, H. P., Chandler, D. G., Benner, S. G., and McNamara, J. P.: Aspect influences on soil water retention and storage, Hydrol. Process., 25, 3836-3842, 2011.

Ghodrati, M. and Jury, W. A.: A field study of the effects of soil structure and irrigation method on preferential flow of pesticides in unsaturated soil, J. Contam. Hydrol., 11, 101-125, 1992.

Grant, L., Seyfried, M., and McNamara, J. P.: Spatial variation and temporal variability of soil water in a snow-dominated, semi-arid region, Hydrol. Process., 18, 3493-3511, 2004.

Gresswell, R. E.: Fire and aquatic ecosystems in forested biomes of North America, T. Am. Fish. Soc., 128, 193-221, 1999.

Hartmann, H. T., Kester, D. E., Davies Jr., F. T., and Geneve, R. L.: Hartmann and Kester's Plant Propagation, Principles and Practices, 8th edition: Boston, Prentice Hall, 2011.

Hinckley, E. S., Ebel, B. A., Barnes, R. T., Anderson, R. S., Williams, M. W., and Anderson, S. P.: Aspect control of water movement on hillslopes near the rain-snow transition of the Colorado Front Range, U.S., Hydrol. Process., in review, 2012.

Ice, G. G., Neary, D. G., and Adams, P. W.: Effects of wildfire on soils and watershed processes, J. Forest., 102, 16-20, 2004.

Iwata, Y., Hirota, T., Hayashi, M., Suzuki, S., and Hasegawa, S.: Effects of frozen soil and snow cover on cold-season soil water dynamics in Tokachi, Japan, Hydrol. Process., 24, 1755-1765, 2010.

Iwata, Y., Nemoto, M., Hasegawa, S., Yanai, Y., Kuwao, K., and Hirota, T.: Influence of rain, air temperature, and snow cover on subsequent spring-snowmelt infiltration into thin frozen soil layer in northern Japan, J. Hydrol., 401, 165-176, 2011.

Kang, S., Kim, S., Oh, S., and Lee, D.: Predicting spatial and temporal patterns of soil temperature based on topography, surface cover and air temperature, Forest Ecol. Manag., 136, 173-184, 2000.

Kasper, T. C. and Bland, W. L.: Soil temperature and root growth, Soil Sci., 154, 290-299, 1992.

Keeley, J. E.: Fire intensity, fire severity and burn severity: a brief review and suggested usage, Int. J. Wildland Fire, 18, 116-126, 2009.

Khumalo, G., Holechek, J., Thomas, M., and Molinar, F.: Soil depth and climatic effects on desert vegetation dynamics, Rangeland Ecol. Manag., 61, 269-274, 2008. 
Kitzberger, T., Brown, P. M., Heyerdahl, E. K., Swetnam, T. W., and Veblen, T. T.: Contingent Pacific-Atlantic Ocean influence on multicentury wildfire synchrony over western North America, P. Natl. Acad. Sci., 104, 543-548, 2007.

Klock, G. O.: Snowmelt temperature influence on infiltration and soil-water retention, J. Soil Water Conserv., 27, 12-14, 1972.

Litaor, M. I., Williams, M., and Seastedt, T. R.: Topographic controls on snow distribution, soil moisture, and species diversity of herbaceous alpine vegetation, Niwot Ridge, Colorado, J. Geophys. Res., 113, G02008, doi:10.1029/2007JG000419, 2008.

Malmon, D. V., Reneau, S. L., and Dunne, T.: Sediment sorting and transport by flash floods, J. Geophys. Res.-Earth, 109, F02005, doi:10.1029/2003JF000067, 2004.

Marr, J. W.: Ecosystems of the east slope of the Front Range in Colorado, University of Colorado Studies, Series in Biology No. 6, University of Colorado, Boulder, CO, 134 pp., 1961.

Massman, W. J. and Frank, J. M.: Effect of a controlled burn on the thermophysical properties of a dry soil using a new model of soil heat flow and a new high temperature heat flux sensor, Int. J. Wildland Fire, 13, 427-442, 2004.

Mataix-Solera, J., Cerdà, A., Arcenegui, V., Jordán, A., and Zavala, L. M.: Fire effects on soil aggregation: A review, Earth-Sci. Rev., 109, 44-60, 2011.

McMichael, B. L. and Burke, J. J.: Soil temperature and root growth, Hortic. Sci., 33, 947-951, 1998.

McNamara, J. P., Chandler, D., Seyfried, M., and Achet, S.: Soil moisture states, lateral flow, and streamflow generation in a semiarid, snowmelt-driven catchment, Hydrol. Process., 19, 40234038, 2005.

McNamara, J. P., Tetzlaff, D., Bishop, K., Soulsby, C., Seyfried, M., Peters, N. E., Aulenbach, B. T., and Hooper, R.: Storage as a metric of catchment comparison, Hydrol. Process., 25, 33643371, doi:10.1002/hyp.8113, 2011.

Minshall, G. W., Brock, J. T., Andrews, D. A., and Robinson, C. T.: Water quality, substratum and biotic responses of five central Idaho (USA) streams during the first year following the Mortar Creek fire, Int. J. Wildland Fire, 10, 185-199, 2001.

Monteith, J. L. and Unsworth, M. H.: Principles of Environmental Physics, 2nd Edn., Routledge, 91 pp., Chapman and Hall, New York, 1990.

Moody, J. A. and Ebel, B. A.: Hyper-dry conditions provide new insights into the cause of extreme floods after wildfire, Catena, 93, 58-63, doi:10.1016/j.catena.2012.01.006, 2012.

Moody, J. A. and Martin, D. A.: Initial hydrologic and geomorphic response following a wildfire in the Colorado Front Range, Earth Surf. Proc. Land., 26, 1049-1070, 2001.

Moody, J. A., Martin, D. A., Oakley, T. M., and Blanken, P. D.: Temporal and spatial variability of soil temperature and soil moisture after a wildfire, US Geological Survey Scientific Investigations Report 2007-5015, US Geological Survey, 89 pp., 2007.

Moreland, D. C. and Moreland, R. E.: Soil Survey of Boulder County Area, Colorado, Natural Resources Conservation Service, United States Department of Agriculture, 91 pp., 1975.

NADP: available at: http://nadp.sws.uiuc.edu/data/ (last access: 22 June 2011), 2011.

Neary, D. G., Klopatek, C. C., DeBano, L. F., and Ffolliott, P. F.: Fire effects on belowground sustainability: a review and synthesis, Forest Ecol. Manag., 122, 51-71, 1999.
Nimmo, J. R. and Miller, E. E.: The temperature dependence of isothermal moisture-vs.-potential characteristics of soils, Soil Sci. Soc. Am. J., 50, 1105-1113, 1986.

Nimmo, J. R. and Winfield, K. A.: Miscellaneous methods [water retention and storage], in: Methods of soil analysis, Part 4 - Physical methods, Soil Science Society of America Book Series No. 5, edited by: Dane, J. H. and Topp, G. C., 710-714, Soil Science Society of America, Madison, Wisconsin, 2002.

Nyman, P., Sheridan, G., and Lane, P. N. J.: Synergistic effects of water repellency and macropore flow on the hydraulic conductivity of a burned forest soil, south-east Australia, Hydrol. Process., 24, 2871-2887, 2010.

Obrist, D., Yakir, D., and Arnone, J. A.: Temporal and spatial patterns of soil water following wildfire-induced changes in plant communities in the Great Basin in Nevada, USA, Plant Soil, 262, 1-12, 2004.

Pechony, O. and Shindell, D. T.: Driving forces of global wildfires over the past millennium and the forthcoming century, P. Natl. Acad. Sci., 107, 19167-19170, 2010.

Peet, R. K.: Forest vegetation of the Colorado Front Range, Plant Ecol., 45, 3-75, 1981.

Pomeroy, J. W., Toth, B., Granger, R. J., Hedstrom, N. R., and Essery, R. L. H.: Variation in surface energetics during snowmelt in a subarctic mountain catchment, J. Hydrometeorol., 4, 702-719, 2003.

Price, M. V. and Waser, N. M.: Effects of experimental warming on plant reproductive phenology in a subalpine meadow, Ecology, 79, 1261-1271, 1998.

Raison, R. J., Woods, P. V., Jakobsen, B. F., and Bary, G. A. V.: Soil temperatures during and following low-intensity prescribed burning in a Eucalyptuspaudflora forest, Aust. J. Soil. Res, 24, 33-47, 1986.

Reneau, S. L., Katzman, D., Kuyumjian, G., Lavine, A., and Malmon, D.: Sediment delivery after a wildfire, Geology, 35, 151154, 2007.

Richards, L. A. and Weaver, L. R.: Moisture retention by some irrigated soils as related to soil-moisture tension, J. Agric. Res., 69, 215-233, 1944.

Rouse, W. R.: Microclimatic changes accompanying burning in subarctic lichen woodland, Arctic Alpine Res., 8, 357-376, 1976.

Schoennagel, T., Sherriff, R. L., and Veblen, T. T.: Fire history and tree recruitment in the Colorado Front Range upper montane zone: implications for forest restoration, Ecol. Appl., 21, 22102222, 2011.

Seyfried, M. S., Grant, L. E., Marks, D., Winstral, A., and McNamara, J.: Simulated soil water storage effects on streamflow generation in a mountainous snowmelt environment, Idaho, USA, Hydrol. Process., 23, 858-873, 2009.

Shakesby, R. A. and Doerr, S. H.: Wildfire as a hydrological and geomorphological agent, Earth-Sci. Rev., 74, 269-307, 2006.

Shanley, J. B. and Chalmers, A.: The effect of frozen soil on snowmelt runoff at Sleepers River, Vermont, Hydrol. Process., 13, 1843-1857, 1999.

Silins, U., Stone, M., Emelko, M. B., and Bladon, K. D.: Sediment production following severe wildfire and post-fire salvage logging in the Rocky Mountain headwaters of the Oldman River Basin, Alberta, Catena, 79, 189-197, 2009.

Smith, H. G., Sheridan, G. J., Lane, P. N. J., Nyman, P., and Haydon, S.: Wildfire effects on water quality in forest catchments: A 
review with implications for water supply, J. Hydrol., 396, 170192, 2011.

Spence, C.: On the relations between dynamic storage and runoff: a discussion on thresholds, efficiency and function, Water Resour. Res., 43, W12416, doi:10.1029/2006WR005645, 2007.

Spence, C.: A paradigm shift in hydrology: Storage thresholds across scales influence catchment runoff generation, Geography Compass, 4, 819-833, 2010.

Stewart, I. T., Cayan, D. R., and Dettinger, M. D.: Changes in snowmelt runoff timing in Western North America under a "business as usual" climate change scenario, Climatic Change, 62, 217-232, 2004.

Stoof, C. R., Wesseling, J. G., and Ritsema, C. J.: Effects of fire and ash on soil water retention, Geoderma, 159, 276-285, 2010.

Stoof, C. R., Vervoort, R. W., Iwema, J., van den Elsen, E., Ferreira, A. J. D., and Ritsema, C. J.: Hydrological response of a small catchment burned by experimental fire, Hydrol. Earth Syst. Sci., 16, 267-285, doi:10.5194/hess-16-267-2012, 2012.

Sweeney, J. R.: Responses of vegetation to fire: a study of the herbaceous vegetation following chaparral fires, Univ. Calif. Publ. Bot. 28, 141-216, 1956.

Topp, G. C. and Ferré, P. A.: Methods for measurement of soil water content: Thermogravimetric using convective oven-drying, in Methods of Soil Analysis, Part 4 - Physical Methods, Soil Science Society of America Book Series: 5, edited by: Dane, J. H. and Topp, G. C., 422-424, Soil Science Society of America, Madison, WI, 2002.

Tromp-Van Meerveld, H. J. and McDonnell, J. J.: Threshold relations in subsurface stormflow: 1. A 147-storm analysis of the panola hillslope, Water Resour. Res., 42, W02410, doi:10.1029/2004WR003778, 2006a.

Tromp-Van Meerveld, H. J. and McDonnell, J. J.: Threshold relations in subsurface stormflow: 2. The fill and spill hypothesis, Water Resour. Res., 42, W02411, doi:10.1029/2004WR003800, $2006 b$.

Trumbore, S. E., Chadwick, O. A., and Amundson, R.: Rapid exchange between soil carbon and atmospheric carbon dioxide driven by temperature change, Science, 272, 393-396, 1996.

United States Department of Agriculture (USDA): Soil Survey Staff, Natural Resource Conservation Service, US Department of Agriculture, Web Soil Survey, available at: http://websoilsurvey. nrcs.usda.gov/ (last access: 29 November 2010), 2010. van Cleve, K., Dyrness, C. T., Viereck, L. A., Fox, J. F., Chapin III, F. S., and Oechel, W.: Taiga ecosystems in interior Alaska, BioScience, 33, 39-44, 1983.

van Genuchten, M. T.: A closed-form equation for predicting the hydraulic conductivity of unsaturated soil, Soil Sci. Soc. Am. J., 44, 892-898, 1980.

van Genuchten, M. T., Leij, F. J., and Yates, S. R.: The RETC code for quantifying the hydraulic functions of unsaturated soils, EPA/600/2091/065, Robert S. Kerr Environmental Research Laboratory, Office of Research and Development, US Environmental Protection Agency, Ada, Oklahoma, 1991.

Veblen, T. T., Hadley, K. S., Nel, E. M., Kitzberger, T., Reid, M., and Villalba, R.: Disturbance regime and disturbance interactions in a Rocky Mountain subalpine forest, J. Ecol., 82, 125-135, 1994.

Walker, J., Raison, R. J., and Khanna, P. K.: Fire, in: Australian Soils: The Human Impact, edited by: Russell, J. S. and Isbell, R. F., 185-216, University of Queensland Press, Brisbane, 1986.

Walker, M. D., Ingersoll, R. C., and Webber, P. J.: Effects of interannual climate variation on phenology and growth of two alpine forbs, Ecology, 76, 1067-1083, 1995.

Westerling, A. L., Hidalgo, H. G., Cayan, D. R., and Swetnam, T. W.: Warming and earlier spring increase Western U.S. forest wildfire activity, Science, 313, 940-943, 2006.

Williams, C. J., McNamara, J. P., and Chandler, D. G.: Controls on the temporal and spatial variability of soil moisture in a mountainous landscape: the signature of snow and complex terrain, Hydrol. Earth Syst. Sci., 13, 1325-1336, doi:10.5194/hess-131325-2009, 2009.

Winkler, R. D.: Changes in snow accumulation and ablation after a fire in south-central British Columbia, Streamline Watershed Management Bulletin, 14, 1-7, 2011.

Woods, S. W. and Balfour, V. N.: The effects of soil texture and ash thickness on the post-fire hydrological response from ashcovered soils, J. Hydrol., 393, 274-286, 2010.

Yoshikawa, K. and Overduin, P. P.: Comparing unfrozen water content measurements of frozen soil using recently developed commercial sensors, Cold Reg. Sci. Technol., 42, 250-256, 2005. 